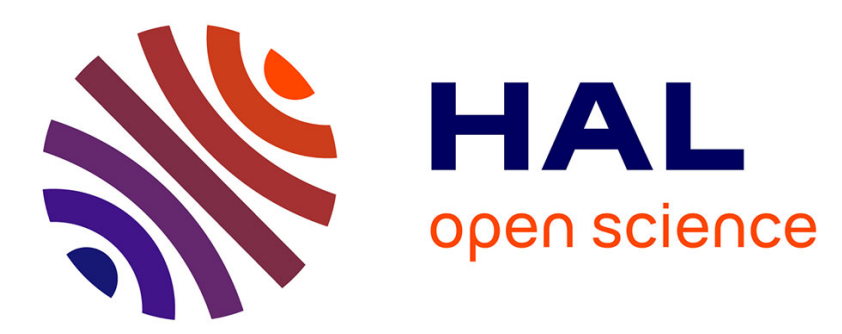

\title{
Virtual dissection and lifestyle of a 165 million-year-old female polychelidan lobster
}

Clément Jauvion, Denis Audo, Sylvain Charbonnier, Jean Vannier

\section{To cite this version:}

Clément Jauvion, Denis Audo, Sylvain Charbonnier, Jean Vannier. Virtual dissection and lifestyle of a 165 million-year-old female polychelidan lobster. Arthropod Structure and Development, 2016, 45

(2), pp.122-132. 10.1016/j.asd.2015.10.004 . hal-01231417

HAL Id: hal-01231417

\section{https://hal-univ-rennes1.archives-ouvertes.fr/hal-01231417}

Submitted on 22 Jan 2016

HAL is a multi-disciplinary open access archive for the deposit and dissemination of scientific research documents, whether they are published or not. The documents may come from teaching and research institutions in France or abroad, or from public or private research centers.
L'archive ouverte pluridisciplinaire HAL, est destinée au dépôt et à la diffusion de documents scientifiques de niveau recherche, publiés ou non, émanant des établissements d'enseignement et de recherche français ou étrangers, des laboratoires publics ou privés. 
Virtual dissection and lifestyle of a 165 million-year-old female polychelidan lobster

Clément Jauvion ${ }^{\mathrm{a}, \mathrm{b} *}$, Denis Audo ${ }^{\mathrm{c} *}$, Sylvain Charbonnier ${ }^{\mathrm{d}}$, Jean Vannier ${ }^{\mathrm{a}}$.

a, Université Claude Bernard Lyon 1, UMR 5276 CNRS, Laboratoire de géologie de Lyon: Terre, Planètes, Environnement, bâtiment GEODE, 2, rue Raphaël Dubois, 69622 Villeurbanne, France. (email: clement.jauvion@etu.univ-lyon1.fr, jean.vannier@univ-lyon1.fr)

b, École Normale Supérieure de Lyon, 46, allée d'Italie, 69364 Lyon cedex 07, France (email: clement.jauvion@ens-lyon.fr)

c, Université de Rennes 1, EA 7316, 263 Avenue du Général Leclerc CS 74205, 35042 Rennes

Cedex, France. (email: denis.audo@univ-rennes1.fr)

d, Muséum national d'Histoire naturelle, Centre de Recherche sur la Paléobiodiversité et les Paléoenvironnements (CR2P, UMR 7207), Sorbonne Universités-MNHN, CNRS, UPMC-Paris6, 57 rue Cuvier, F-75005, Paris, France. (email: scharbonnier@mnhn.fr)

*These authors contributed equally to this work. Correspondence and requests for material should be addressed to C. J. or D. A. (email: clement.jauvion@ens-lyon.fr and denis.audo@edu.mnhn.fr)

\begin{abstract}
Polychelidan lobsters are fascinating crustaceans that were known as fossils before being discovered in the deep-sea. They differ from other crustaceans by having four to five pairs of claws. Although recent palaeontological studies have clarified the systematics and phylogeny of the group the biology of extant polychelidans and first of all their anatomy are poorly documented. Numerous aspects of the evolutionary history of the group remain obscure, in particular how and when polychelidans colonized the deep-sea and became restricted to it. Surprisingly, the biology of extant polychelidans and anatomy of all species, fossil and recent, are poorly documented. Here, X-ray microtomography (XTM), applied to an exceptionally wellpreserved specimen from the La Voulte Lagerstätte, reveals for the first time vital aspects of the external and internal morphology of Voulteryon parvulus (Eryonidae), a 165-million-year-old polychelidan: 1) its mouthparts (maxillae and maxillipeds), 2) its digestive tract and 3) its reproductive organs. Comparisons with dissected specimens clearly identify this specimen as a female with mature ovaries. This set of new information offers new insights into the feeding and reproductive habits of Mesozoic polychelidans. Contrasting with other Jurassic polychelidans that lived in shallow-water environments, $V$. parvulus spawned in, and probably inhabited, relatively deep-water environments as do the survivors of the group.
\end{abstract}

Keywords: Crustacea, X-Ray tomography, Jurassic, La Voulte-sur-Rhône, digestive system, reproductive system

\title{
1 Introduction
}

Polychelidan lobsters are fascinating crustaceans that were first described as fossils in the Late Jurassic of Southern Germany before being recognized half a century later in extant deep-water environments during the celebrated Challenger Expedition (Wyville Thompson 1873). By contrast with lobsters and shrimps, they are characterized by an unusual dorso-ventrally flattened shape and the presence of four to five pairs of chelate appendages (Fig. 1A) that makes them 
unique among decapods and often regarded as the sister group of Eureptantia (i.e. lobsters, hermit crabs and true crabs). Unlike extant polychelidans which are restricted to deep-water and blind, Mesozoic representatives of the group display prominent bulbous eyes (Figs. 1B, 1C). The majority of fossil polychelidan lobsters described to date are associated with shallow-water settings (e.g. Garassino \& Schweigert 2006, Audo et al. 2014a, 2014b) and have faunal associates that are typical of these marine environments. The deepest occurrence of fossil polychelidans is the La Voulte Lagerstätte (Charbonnier 2009, Audo et al. 2014) which is supposed to have been deposited in bathyal conditions (Charbonnier et al. 2007a). Although recent studies based on exoskeletal characters have helped to clarify many aspects of their phylogeny (Ahyong 2009, Karasawa et al. 2013, Audo 2014), still very little is known concerning the internal anatomy of both fossil and extant representatives of the group. The only anatomical description of an extant polychelidan is that of Polycheles typhlops Heller, 1862 which concentrates on the reproductive system to the exclusion of the other vital organs (Cabiddu et al. 2008). The exceptional preservation of the fossils from the La Voulte Lagerstätte gave us the chance to use X-ray microtomography (XTM) as a non-invasive tool to explore for the first time the internal and external anatomy of a Middle Jurassic (Callovian; ca $165 \mathrm{Ma}$ ) polychelidan lobster. Our study reveals unprecedented details of the mouthparts, digestive and reproductive systems in a single specimen of Voulteryon parvulus Audo et al. 2014 (Figs 1B-1C) and opens the way to comparisons with modern polychelidans. The detailed reconstructions obtained via XTM also offer new insights into the lifestyles of Mesozoic polychelidan lobsters.

\subsection{The La Voulte biota}

The fossiliferous deposits of the La Voulte Lagerstätte are dated from the Middle Jurassic (Callovian) based on ammonite biostratigraphy (Roman 1930, Elmi 1967, 1990). They consist in relatively thin interval of marls (thickness: $c a$ 4-5 m) topped by iron ore bodies (thickness: $c a 15$ $\mathrm{m})$. Fossils occur either in early diagenetic concretions within which they are three-dimensionally preserved or in surrounding marls where they are flattened and preserved in pyrite and phosphate.

La Voulte Lagerstätte is famous for the exceptional preservation of highly diverse decapod crustacean fauna (e.g., dendrobranchiate shrimps, astacidean, polychelidan, erymidan and glypheidean lobsters; Charbonnier et al. 2010, Charbonnier et al. 2013). Other arthropod groups occur in this locality such as thylacocephalans (Secrétan 1985, Vannier et al. 2006, and this issue) and pycnogonids (Charbonnier et al. 2007b). Arthropods are associated with remarkably wellpreserved soft-bodied animals such as the assumed oldest octopus (Wilby 2001, Etter 2002, Fischer 2003), annelids, sipunculid worms, and hemicordates (Alessandrello et al. 2004).

Echinoderms are represented by very abundant and fully articulated brittle stars and multi-armed sea stars (Villier et al. 2009). Actinopterygian fishes, coelacanths, sharks, and one marine crocodile have also been reported (Charbonnier 2009). The abundance of brittle stars indicates eutrophic conditions (Cartes \& Sardà 1992) as it is the case in modern marine environments.

Palaeogeographic reconstructions for the Callovian place the La Voulte Lagerstätte along the western margin of the Tethys Ocean (Enay et al. 1993), which was characterised by a complex submarine palaeotopography of tilted blocks (Charbonnier et al. 2007a). Thus, the La Voulte Lagerstätte was situated near the slope-basin transition with a water depth most probably exceeding $200 \mathrm{~m}$ (Charbonnier et al. 2007a).

Hydrothermal activity might have played an important role in the mineralization of soft tissues that probably occurred via diverse and complex pathways (Wilby et al. 1996). The La Voulte biota is a key to the understanding of past marine deep environments for it stands as one of the most complete and richest locality for the Mesozoic at our disposal (Charbonnier 2009). 


\subsection{Institutional acronyms}

IRD, Institut de Recherche pour le Développement; MNHN, Muséum national d'Histoire naturelle, Paris (F, collection de paléontologie; IU, collection de Zoologie - Arthropodes marins); PNI, Pro Natura International; UPNG, University of Papua New Guinea.

\section{Material and Methods}

\subsection{Fossil material}

Voulteryon parvulus Audo, Schweigert, Saint Martin \& Charbonnier, 2014 is known from the holotype (total length and shield length 15 and $8.5 \mathrm{~mm}$, respectively) and from one paratype (shield length $8.4 \mathrm{~mm}$ ). The present study is based on a single specimen, the holotype of $V$. parvulus. This specimen is preserved in three dimensions within a carbonated (sideritic) nodule. Only one half of this nodule was available for study, its counterpart being either destroyed during preparation work or lost. The dorsal part of the exoskeleton is exposed whereas the ventral side of the animal remains entirely embedded in rock and therefore unobservable. $V$. parvulus belongs to Eryonidae (Audo et al. 2014c). Due to its relatively small size the holotype was first considered to represent a juvenile stage of a larger eryonid but was shown to be an adult (for comparison between eryonid species, see Audo et al. 2014b: Table 1). The holotype of $V$. parvulus is deposited in the collections of the Muséum national d'Histoire naturelle, Paris (MNHN.F.A50708). Extant polychelidan lobsters from the zoological collections of the Muséum national d'Histoire naturelle, Paris, were used for comparative studies. A male specimen of Polycheles typhlops (MNHN.IU.20137841: Fig. 2) was dissected in order to obtain more information on the internal organs (Cabiddu et al. 2008). This specimen was collected during the "Our Planet Reviewed" 2012 expedition to Papua Niugini "Madang" (MNHN, PNI, IRD, UPNG), trawled at 440 meters depth in Dogreto Bay, Bismarck sea, Papua New Guinea (station: CP4066).

The terminology used in the present paper is based on Glaessner (1969) for the general decapod anatomy, Galil (2000) and Audo et al. (2014a-c) for descriptive aspects specific to polychelidans. We follow the terminology of Meiss \& Normann (1977) for the digestive system.

\subsection{X-ray microtomography}

The specimen was imaged with a $\mathrm{v} \mid$ tome $\mid \mathrm{x} 240 \mathrm{~L}$ tomograph (GE Sensing \& Inspection Technologies Phoenix $\mathrm{X} \mid$ ray) equipped with a microfocus $240 \mathrm{kV} / 320 \mathrm{~W}$ tube delivering a current/voltage of $485 \mu \mathrm{A} / 95 \mathrm{kV}$. Microtomography was performed at the AST-RX technical platform of the Muséum national d'Histoire naturelle, Paris. Data were processed to obtain a series of virtual slices with a voxel size (cubic voxel) of $9.55 \mu \mathrm{m}$. Virtual slices were saved as a series of image files in 16 bits greyscale indicating differences in absorption of X-ray within the nodule (darker for low absorption, brighter for high absorption). 2007 virtual slices with a resolution of $1651 \times 1041$ pixels were thus obtained. Their examination, often slice by slice, allowed drawing the accurate outlines of the fossilized structures. VG-Studio MAX 2.2 (C) Volume Graphics) and Mimics 17.0 (C Materialise) were used for reconstructing the three dimensional aspect of the exoskeleton and the mouthparts, antennae and internal organs, respectively.

\section{Results}

\subsection{Eyes (Figs 1B-C, 3-5)}

The eyes of Voulteryon parvulus Audo et al. 2014 are bulbous, prominent and protrude outside the cephalic shield laterally. Their diameter is ca $9 \%$ of the total length of the animal. Although not revealed by XTM, the visual surface of the eyes shows numerous ommatidia (Audo et al. in preparation). 


\subsection{Cephalic appendages (Figs 4, 5A)}

The antennula (first antenna, a1: Fig. 5E) is short and composed of a tripartite peduncle: a bulbous proximal part, a stout cylindrical intermediate part and a cylindrical distal part bearing two flagella of undetermined length (broken in the single studied specimen). The antenna (second antenna, a2) has a short coxa with a small inward projection (possibly the renal process), a stout triangular basis, a subtriangular merus, and a cylindrical carpus carrying a flagellum of undetermined length. No scaphocerite (exopod) was observed. The mandible (md: Fig. 5G) consists of a large protopod and a stocky mandibular palp. The mandibular protopod forms a wide incisor process (molar process indistinct or lacking) and an elongated coxal body. The first maxilla is not preserved. The second maxilla $(\mathrm{mx} 2$ : Fig. $5 \mathrm{H})$ has a stout ischium, a stocky merus and carpus, a cylindrical propodus and a short dactylus. Dactylus, propodus and carpus of second maxilla point slightly forward and upward, right under the anterior part of the mandibles.

\subsection{Thoracic appendages (Figs 3-4, 5A)}

The first maxilliped is poorly preserved. The second maxilliped (mxp2: Fig. $5 \mathrm{H}$ ) is composed of wide, indistinct basal podomeres (ischium, basis and coxa?) followed by a short and flat merus, a flat carpus, a stout propodus and short dactylus. The third maxilliped (mxp3: Fig. 5H) has a short proximal part (basis and coxa are indistinct), a large, flattened subtriangular ischium and four stout subcylindrical podomeres (carpus-merus). The first pereiopod (P1) is chelate and larger than the other pereiopods. It has a very short and stout coxa and basis (poorly preserved), a short ischium, a long merus, a short subtriangular carpus, a long propodus with a straight pollex, and a long dactylus curving distally. The second to fourth pereiopods (P2-P4) are also chelate and decrease in size posteriorly. The last pereiopod (P5) is achelate.

\subsection{Digestive system (Fig. 5)}

A large ovoid pouch lying directly above the mandibles occurs in the anterior part of the body of $V$. parvulus (Fig. 5A-5B). It is followed by a conical structure, and a subcylindrical canal, running to the distal extremity of the pleon (Fig. 5A-5B). The dissection of a recent specimen of Polycheles typhlops (Fig. 2) and comparisons with the assumed anatomical ground pattern of decapod crustaceans allows us to identify this three-fold structure as the digestive tract of the animal. The anteriormost wide and ovoid structure corresponds to the cardiac stomach of decapod crustaceans. The conical structure is interpreted as the pyloric stomach (Icely and Nott 1992). The subcylindrical canal corresponds to the intestine and extends from the mid-length of the cephalic shield to the sixth pleonal somite where it ends up abruptly (anus).

Additional supporting evidence is brought by virtual sections (Figs 5C-5F) through the boundary between the cardiac and pyloric chambers of the stomach that shows 1) ossicles lining the pyloric stomach (ampulary roof ossicles and ampulary inferior ossicles: Fig. 5C) and 2) teeth in the rear part of the cardiac stomach (Fig. 5D-5E). This configuration is typical of the gastric mill of decapod crustaceans (Meiss \& Normann 1977, Watling 2013) which has teeth and small ossicles for grinding food and bristles for filtering small particles. It is also that of the gastric mill of P. typhlops (see dissection Fig. 2D). To summarize, the gastric mill of $V$. parvulus consists of: 1) a wide urocardiac ossicle bearing a median tooth, 2) a pair of zygocardiac ossicles bearing the lateral teeth of the gastric mill and 3) a pair of exopyloric (?) ossicles framing the urocardiac ossicle.

The hepatopancreas (paired midgut glands) was not have been observed by XTM in $V$. parvulus. Unlike other anatomical structures, the hepatopancreas probably decayed rapidly after death before early mineralization of soft tissues could operate.

\subsection{Reproductive system (Figs 5A-5B)}


$V$. parvulus displays two lateral structures overlying the digestive tract and connected dorsally by a bridge. The whole structure stretches along the dorsal midline of the thoracic cavity and fills about one third of the shield volume. It is interpreted as the female reproductive organs based on the following comparisons with recent polychelidans and other crustacean groups.

Females of $P$. typhlops (Cabiddu et al. 2008: fig. 2) have massive gonads that closely resemble the cross-shaped structures of $V$. parvulus. The testicles of males (dissected specimen Figs 2A-2B) form comparable structures but much thinner (see dissection, Fig. 2A-2B) than those of $V$. parvulus. Close resemblances with the massive, paired, bridged ovaries of other decapod crustaceans (e.g. Majoidea: González-Pisani et al. 2012) also support our interpretation. Thus, the ovary (Fig. 5A-5B) of $V$. parvulus is divided into (1) a cephalic horn extending obliquely laterally and anteriorly from the midline and (2) a thoracic horn running longitudinally. The cephalic and thoracic horns are $c a 1$ and $0.5 \mathrm{~mm}$ in diametre, respectively. The holotype of $V$. parvulus is therefore a female specimen. In addition, comparisons with developmental stages of the gonads in P. typhlops (Cabiddu et al. 2008 ) indicate that the ovaries of $V$. parvulus from La Voulte probably correspond to the "ripening" or "mature" stage observed in extant polychelidan (Cabbidu et al. 2008: fig. 2e-2f) stages. The presence of mature ovaries implies that the studied specimen, despite its very small size compared to other fossil polychelidan lobsters, was most probably a sexually mature adult.

\subsection{Respiratory and cardiovascular system (Figs 5A-5B)}

A pair of large cavities occur along the inner side of the shield of $V$. parvulus which extend anteriorly into a tapering syphon. These cavities are interpreted as the branchial chambers but gills are not evident. Cardiovascular structures such as the heart could not be found. Their absence may be due to their rapid decay or to the lack of sufficient contrast with the surrounding material, their dorsal position inducing exposure to higher energy X-ray.

\subsection{Muscles (Figs 4D, 5A-5B)}

A pair of flat structures that seem to adhere to the inner side of shield was observed in $V$. parvulus. They are positioned on each side of the midline and more precisely in the area delineated by the cervical and postcervical grooves. Direct comparisons with P. typhlops indicate that they most likely represent the dorsal end of the mandible adductor muscles (mam1: Figs 4D, 5A-5B; Figs 2A-2C). The muscular connections (mam2: Figs 2A-C) to the coxa of the mandibles are not preserved in the fossil specimen. These muscular structures are especially thin in P. typhlops. It is thus hardly surprising that they do not occur in $V$. parvulus.

\section{Discussion}

\subsection{Systematic placement}

Audo et al. (2014c) ascribed Voulteryon to Eryonidae based on several characters of the dorsal exoskeleton such as the depth of cervical and postcervical incisions. Our XTM reconstruction of the ventral side and appendages of the animal indicates that the fourth pair of pereiopods is chelate. This important characteristic is very rare among decapod crustaceans (Haug et al. 2015) and confirms the assignment of Voulteryon to the Polychelida. Moreover, our reconstruction reveals that the third maxillipeds of $V$. parvulus possess a subtriangular ischium, which is typical of all Eryonidae except Knebelia (Audo 2014). Audo et al. (2014c) noted the narrowness of the pleon in most adult eryonids, a characteric that normally identify juveniles in other crustacean groups. The narrow pleon of the adult ovigerous female described here is an additional good piece of evidence to support the placement of Voulteryon within the Eryonidae.

\subsection{Morphological conservatism in polychelidan lobsters}


Voulteryon parvulus and extant Polychelidae resemble each other by important exoskeletal features such as their dorsoventrally flattened body, their chelate fourth pereiopods, and the lack of a rostrum as well as the presence of cervical and postcervical incisions cutting through the shield lateral margins. Contrasting with extant deep-sea Polychelidae, $V$. parvulus had well-developed eyes, a shield outline not confluent in outline with the pleon (exception: the extant Cardus crucifer Thomson, 1873 does display the same characteristic) and lacks a scaphocerite (the exopod of antenna). XTM clearly indicates that resemblances between Mesozoic and extant polychelids are not restricted to external exoskeletal features but also concern their anatomy. Typically, the cardiac and pyloric stomachs which show a great variability of shapes in reptantians (Meiss \& Norman 1977) are almost identical in the extant P. typhlops and the Middle Jurassic $V$.parvulus.- i.e. a large ovoid cardiac stomach connected ventrally to the mouth and a conical pyloric stomach (respectively: Figs 2A-2C, Figs 5A-5B). These shared features probably belong to the ground pattern of polychelidan and remained unchanged over the last 165 million years. Minor internal differences between P. typhlops and $V$. parvulus do exist but concern minor details of the stomach structure. For example, the ampullary roof ossicles of the pyloric stomach are thicker in $V$. parvulus than in P. typhlops (compare Figs 2D and 5C). Extant polychelidan lobsters provide a good and detailed example of morphological conservatism and variations through time among crustaceans.

\subsection{Lifestyle}

Little is known concerning the lifestyles of extant polychelidan lobsters, mainly because their deep-sea habitat (generally from $500 \mathrm{~m}$ to $1500 \mathrm{~m}$, up to $5000 \mathrm{~m}$ : Galil 2000) is hardly accessible to observers. They are believed to bury themselves (sensu Faulkes 2013) in sediment (Firth \& Pequegnat 1971, Gore 1984, Ahyong 2009). Decapods use a wide variety of techniques and appendages for burying, be it head first or pleon first (Faulkes 2013). Polychelidans undoubtedly bury themselves pleon first (Fig. 6), using their tail-fan (uropods and telson; Firth \& Pequegnat 1971) to enter the sediment (perhaps somewhat as the similarly flattened slipper lobsters do: Faulkes 2006). This habit may explain why they often remain undetected by Remotely Operated Underwater Vehicles (see Jones et al. 2009 for one of the rare in vivo observation). However, the three-dimensional morphology of $V$. parvulus does not suggest such a burying lifestyle. The shield of Voulteryon as observed in dorsal view is far broader than the pleon, which is, according to Ahyong (2009) unconsistent with a burying lifestyle.

Extant Polychelidae do not possess molar processes on their mandible. For this reason, food items tend to be swallowed as a whole (Cartes \& Abelló 1992). The gut contents of Polychelidae indicate that they are predators of small benthic invertebrates and also opportunistic scavengers (Firth \& Pequegnat 1971, Lagardère 1973, Gore 1984, Cartes \& Abelló 1992). The gut of $V$. parvulus contains undetermined fragments of food (Fig. 5F) that do not allow inferring any food source or precise feeding habit. These poorly preserved gut contents do not seem to be strongly mineralized and show no visible skeletal parts). Their exact origin (plant, animal or detritus origin) cannot be ascertained.

Polychelidan lobsters belong to the Pleocyemata. As such, females carry their eggs on their pleopods until hatching. No eggs attached to pleopods are known in fossil polychelidan lobster. The large size and swollen shape of the ovaries of the studied specimen strongly suggest that we have a mature female probably ready to spawn. The exceptionally good preservation of this specimen excludes horizontal or vertical transportation over long distances. V. parvulus most probably reproduced in the deep-water environment of La Voulte and was fossilized in situ. This situation contrasts markedly with that of the majority of Mesozoic eryonids that had ecological preferences for shallow water settings (e.g. Late Jurassic localities such Solnhofen, Eichstätt, Canjuers or Cerin (Garassino \& Schweigert 2006, Charbonnier \& Garassino 2012, Audo et al. 2014a, b) where the eryonid fauna is diverse and abundant with apparently co-occurring adults and juveniles (e.g., Audo et al. 2014b). 
In extant polychelidans, ovigerous females perform vertical migrations (Santucci 1933, Firth \& Pequegnat 1971) through the water column as a result of larval requirements (Bernard 1953). $V$. parvulus may have had a comparable reproductive behaviour. This might explain why $V$. parvulus is unusually rare at La Voulte.

\section{Conclusion}

Paradoxically, we are experiencing the same problems that pioneer scientists faced when they first discovered fossil polychelidans in the middle of the nineteenth century: we lack information on extant Polychelida to compare with the data from fossil specimens. By using XTM, we obtained new information on the internal anatomy of Mesozoic polychelidan lobsters that, in some way, goes beyond the current knowledge on the biology of the living representatives of the group. It is therefore crucial to re-explore the anatomy of extant polychelidans with modern techniques such as XTM and also to collect more in-situ observations of deep-sea species.

\section{Acknowledgments}

The authors are grateful to Miguel Garcia Sanz (MNHN), Florent Goussard (MNHN) and Damien Germain (MNHN) for technical assistance with the XTM and imaging system. We also thank Paula Martin-Lefèvre and Laure Corbari (MNHN) for providing specimens of extant P. typhlops and Jean-Michel Pacaud (MNHN), for access to the collections of fossil invertebrates. We also thank all people that made the 2012 "Madang" expedition (MNHN, PNI, IRD, UPNG) possible: its principal instigators, Philippe Bouchet, Claude Payri and Sarah Samadi; the companies which contributed to fund this expedition, Total Foundation, Prince Albert II of Monaco Foundation, Fondation EDF, Stavros Niarchos Foundation and Entrepose Contracting; and finally the in-kind support from the Divine Word University (Papua New Guinea).

The authors thank the two reviewers of this paper, Dr Jonas Keiler and Dr Shane T. Ahyong for their kind and constructive reviews.

\section{References}

Ahyong, S. T. 2009. The Polychelidan Lobster: Phylogeny and Systematics (Polychelida: Polychelidae). In J. W. Martin, K. A. Crandall \& D. L Felder (Eds), Decapod Crustacean Phylogenetics. Crustacean Issues, Volume 18. CRC Press, Taylor \& Francis Group, Boca Raton, London, New York, pp. 369-396.

Alessandrello, A., Bracchi, G. and Riou, B., 2004. Polychaete, sipunculan and enteropneust worms from the Lower Callovian (Middle Jurassic) of La Voulte-sur-Rhône (Ardèche, France). Memorie della Società Italiana di Scienze Naturali e del Museo Civico di Storia Naturale di Milano 32, 1-17.

Audo, D., 2014 Les Polychelida, un groupe de crustacés énigmatiques : systématique, histoire évolutive, paléoécologie et paléoenvironnements. Muséum national d'Histoire naturelle. $\mathrm{PhD}$ thesis.

Audo, D., Charbonnier, S., Schweigert, G. and Saint Martin, J.-P. 2014a. New eryonid crustaceans from the Late Jurassic Lagerstätten of Cerin (France), Canjuers (France), Wattendorf (Germany) and Zandt (Germany). Journal of Systematic Palaeontology 12, 459-479.

Audo, D., Schweigert, G., Haug, J.T., Haug, C., Saint Martin, J.-P., and Charbonnier, S., 2014b. Diversity and palaeoecology of the enigmatic genus Knebelia (Eucrustacea, Decapoda, Eryonidae) from Upper Jurassic Plattenkalks in Southern Germany. Palaeontology 57, $397-$ 416.

Audo, D., Schweigert, G., Saint Martin, J.-P. and Charbonnier, S., 2014c. High biodiversity in Polychelida crustaceans from the Jurassic La Voulte-sur-Rhône Lagerstätte. Geodiversitas 36, 489-525.

Bernard, F., 1953. Decapoda Eryonidae (Eryoneicus et Willemoesia). Dana Report 37, 1-93. 
Cabiddu, S., Follesa, M.C., Gastoni, A., Porcu, C. and Cau, A. 2008. Gonad development of the deep-sea lobster Polycheles typhlops (Decapoda: Polychelidae) from the central western mediterannean. Jounral of Crustacean Biology 28, 494-501.

Cartes, J.E. and Abelló, P. 1992. Comparative feeding habits of polychelid lobsters in the Western Mediterranean deep-sea communities. Marine ecology progress series. Oldendorf, 84(2), 139150.

Cartes, J.E. and Sardà F. 1992. Abundance and diversity of decapod crustaceans in the deepCatalan Sea (Western Mediterranean). Journal of Natural History 26, 1305-1323.

Charbonnier, S., 2009. Le Lagerstätte de La Voulte : un environnement bathyal au Jurassique. Mémoires du Muséum national d'Histoire naturelle 199, 1-272.

Charbonnier, S., Garassino, A., Schweigert, G. and Simpson, M., 2013. A worldwide review of fossil and extant glypheid and litograstrid lobsters (Crustacea, Decapoda, Glypheoidea). Mémoires du Muséum national d'Histoire naturelle 205, 1-304.

Charbonnier, S., Vannier, J., Gaillard, C., Bourseau, J.-P. and Hantzpergue, P., 2007a. The La Voulte Lagerstätte (Callovian): evidence for a deep water setting from sponge and crinoid communities. Palaeogeography, Palaeoclimatology, Palaeoecology 250, 216-236.

Charbonnier, S., Vannier, J., Hantzpergue, P. and Gaillard, C., 2010. Ecological significance of the arthropod fauna from the Jurassic (Callovian) La Voulte Lagerstätte. Acta Palaeontologica Polonica 55, 111-132.

Charbonnier, S., Vannier, J., and Riou, B., 2007b. New sea spiders from the Jurassic La Voultesur-Rhône Lagerstätte. Proceedings of the Royal Society B: Biological Sciences. 274, 25552561.

Elmi, S., 1967. Le Lias supérieur et le Jurassique moyen de l'Ardèche. Documents des Laboratoires de Géologie de la Faculté des Sciences de Lyon 19, 257-507.

Elmi, S., 1990. Stages in the evolution of late Triassic and Jurassic carbonate platforms: the western margin of the Subalpine Basin (Ardèche, France). In: Tucker, M.E., Wilson, J.L., Crevello, P.D., Sarg, J.R., Read, J.F. (Eds.), Carbonate Platforms, Facies, Sequences and Evolution 9. Blackwell Scientific Publications, Oxford, London, Edinburgh, Boston, Melbourne, pp. 109-144.

Enay, R., Guiraud, R., Ricou, L.E., Mangold, C., Thierry, J., Cariou, E., Bellion, Y., Dercourt, J., 1993. Callovian (162 to $158 \mathrm{Ma}$ ). In: Dercourt J., Ricou, L.E., Vrielynck, B. (Eds.), Atlas Tethys - Palaeoenvironmental maps, Explanatory notes. Gauthier-Villars, Paris, pp. 81-95.

Etter, W., 2002. La Voulte-sur-Rhône: exquisite cephalopod preservation. In: Bottjer, D.J., Etter, W., Hagadorn, J.W. and Tang, C.M. (Eds), Exceptional fossil preservation. Columbia University Press, New York, pp. 293-305.

Faulkes, Z., 2006. Digging mechanisms and substrate preferences of shovel nosed lobsters, Ibacus peronii (Decapoda: Scyllaridae). Journal of Crustacean Biology 26, 69-72.

Faulkes, Z., 2013. Morphological Adaptations for Digging and Burrowing. In: Watling, L. \& M. Thiel (Eds), The Natural History of Crustacea, vol. 1. Oxford University Press, Oxford, pp. 276-295.

Firth, R. M. \& Pequegnat, W. E., 1971. Deep-sea lobsters of the families Polychelidae and Nephropidae (Crustacea, Decapoda) in the Gulf of Mexico and Caribbean Sea. Texas A \& M University, Department of Oceanography, 106 pp.

Fischer, J.-C., 2003. Invertébrés remarquables du Callovien inférieur de la Voulte-sur-Rhône (Ardèche, France). Annales de Paléontologie 89, 223-252.

Galil, B.S., 2000. Crustacea Decapoda: review of the genera and species of the family Polychelidae, Wood-Mason 1874. Mémoires du Muséum national d'histoire naturelle, 184, 285-387.

Galil, B.S., 2013. On a collection of Polychelidae from Papua New Guinea (Crustacea, Decapoda, Polychelida). Zootaxa 35, 495-502. 
Garassino, A. \& Schweigert, G. 2006. The Upper Jurassic Sonhofen decapod crustacean fauna: review of the types from old descriptions. Part I. Infraorders Astacidea, Thalassinidea, and Palinura. Memorie della Società Italiana di Scienze Naturali e del Museo Civico di Storia Naturale di Milano, 34(1), 1-64.

Glaessner M.F., 1969. Decapoda. In: Moore, R.C. and Teichert, C. (Eds), Treatise on Invertebrate Paleontology, Part R. Arthropoda, 4(2). Geological Society of America, Boulder, Colorado and University of Kansas Press, Lawrence, Kansas, R400-R533.

González-Pisani, X., Baron, P., and López Greco, L. S. (2012). Functional anatomy of the female reproductive systems of two spider crabs (Decapoda, Majoidea). Invertebrate Biology, 131(1), 61-74.

Gore, R.H., 1984. Abyssal Lobsters, Genus Willemoesia (Palinura, Polychelidae), from the Venezuela Basin, Caribbean Sea. Proceedings of the Academy of Natural Sciences of Philadelphia, 136, 1-11.

Haug, J.T., Audo, D., Haug, C., Abi Saad, P., Petit, G. and Charbonnier S., 2015. Unique occurrence of polychelidan lobster larvae in the fossil record and its evolutionary implications. Gondwana Research 28, 869-874.

Heller, C., 1862. Neue Crustaceen, gesammelt während der Weltumseglung der k.k. Fregatte Novara. Zweiter vorläufiger Bericht. Verhandlungen der kaiserlich-königlichen zoologischbotanischen Gesellschaft in Wien 12: 519-528.

Icely, J.D. and Nott, J.A., 1992. Digestion and absorption: digestive system and associated organs. In: Harrison, F.E. and Humes, A.G. (Eds), Microscopic Anatomy of Invertebrates, vol. 10, Wiley-Liss, New York, pp. 147-201.

Lagardère, J.-P. 1973. Distribution des Décapodes dans le sud du Golfe de Gascogne. Revue des Travaux de l'Institut des Pêches Maritimes, 37(1), 77-95.

Meiss, D.E. and Norman, R.S. 1977. Comparative Study of the Stomatogastric System of Several Decapod Crustacea. I. Skeleton. Journal of Morphology 152, 21-53.

Roman F. 1928. 1. - Horizon à nodules de crustacés et poissons. In Sayn G. \& Roman F. (Eds), Monographie stratigraphique et palaéontologique du Jurassique moyen de la Voulte-surRhône. Travaux du laboratoire de géologie de la faculté des sciences de Lyon, Lyon, 11 (13), pp. 1-165, pl. 1-12.

Santucci, R., 1933. Biologia del fondo a "Scampi" nel Mar Ligure. I. Polycheles typhlops Heller. Memorie Reale Comitato talassografico italiano 199, 1-48.

Secrétan, S., 1985. Conchyliocarida, a class of fossil crustaceans: relationships to Malacostraca and postulated behaviour. Transactions of the Royal Society of Edinburgh 76, 381-389.

Vannier, J., Chen, J.-Y., Huang, D.-Y., Charbonnier, S. and Wang, X.-Q., 2006. The Early Cambrian origin of thylacocephalan arthropods. Acta Palaeontologica Polonica 51, 201-214.

Villier, L., Charbonnier, S. and Riou, B., 2009. Sea Stars from Middle Jurassic Lagerstätte of La Voulte-sur-Rhône (Ardèche, France). Journal of Paleontology 83, 389-398.

Watling, L., 2013. Feeding and Digestive System. In: Watling, L. \& M. Thiel (Eds), The Natural History of Crustacea, vol. 1. Oxford University Press, Oxford, pp. 237-260.

Wilby, P.R., 2001. La Voulte-sur-Rhône. In: Briggs, D.E.G. and Crowther, P.R. (Eds), Palaeobiology II. Blackwell Publishing, Malden, Oxford, Victoria, pp. 349-351.

Wilby, P.R., Briggs, D.E.G. and Riou, B., 1996. Mineralization of soft-bodied invertebrates in a Jurassic metalliferous deposit. Geology 24 (9), 847-850.

Wyville Thompson, C. 1873. Notes from the "Challenger" IV. Nature, 8(183), 246-249.

\section{Captions}


Figure 1: Dorsal morphology of recent and fossil polychelidan lobsters. A, Polycheles coccifer Galil, 2000 ( $\lesssim$ ) from Papua New Guinea, Tami Island, Huon Gulf, ca 410 m (@Tin-Yam Chan, National Taiwan Ocean University; CP3645, Biopapua expedition 2010; see Galil 2013 for details). B, C, Voulteryon parvulus Audo, Schweigert, Saint Martin and Charbonnier, 2014 ( $(+)$ from the Middle Jurassic La Voulte Lagerstätte, France. Abbreviations: a, branchiocardiac groove; a1, antennula; a2, antenna; ala, anterolateral angle; ba, basipodite; bc, branchial carina; c, postcervical groove; ca, carpus; ci, postcervical incision; $\mathbf{d}$, gastro-orbital groove; da, dactylus; ds, disc-shaped structure; $\mathbf{e}_{1} \mathbf{e}$, cervical groove; ei, cervical incision; en, endopod of uropod; ex, exopod of uropod; fm, frontal margin; is, ischium; me, merus; o, eye; P1-P5, pereiopods 1-5; pa, palm; pc, postcervical carina; pla, posterolateral angle; pr, postrostral carina; pro, propodus; px, pollex; s1-s6, pleonite 1-6; sc, scaphocerite; $\mathbf{t}$, telson; ur, uropod. Scale bars: $2 \mathrm{~cm}$ in $A$ and $5 \mathrm{~mm}$ in $B$.

Figure 2: Anatomy of Polycheles typhlops ( $)$ from Papua New Guinea, Bismarck sea, Dogreto Bay, 440 m (station CP4066, "Madang" expedition 2012). A-B, dorsal view of a dissected specimen immersed in water with cephalothorax opened between branchial carina to show internal organs (heart removed). C, isolated mandible with attached abductor muscle, dorsal view. D, cardiac stomach opened ventrally to reveal gastric mill teeth. Abbreviations: ai, ampulary inferior ossicle; ar, ampulary roof ossicles; bs, branchiostegite; ch, testicular cephalic horn; ci, postcervical incision cs, cardiac stomach; csw, cardiac stomach wall; $\mathbf{d t}$, digestive tract; ei, cervical incision; $\mathbf{g}$, gill; $\mathbf{h p}$, hepatopancreas; ip, mandible incisor process; lt, lateral gastric mill teeth; $\mathbf{m}$, muscle; mam1, thick dorsal mandible abductor muscle; mam2, thin median mandible muscle; $\mathbf{m d p}$, mandibular palp; ms, mesocardiac ossicle; o, eye; ps, pyloric stomach; pt, pterocardiac ossicle; s1, pleonite 1; st, part of the sternite; th, testicular thoracic horn; uc, urocardiac ossicle; $\mathbf{z c}$, zygocardiac ossicle. Scale bars: $1 \mathrm{~cm}$ in A-B and $5 \mathrm{~mm}$ in C-D.

Figure 3: XTM surface reconstruction of the ventral surface of Voulteryon parvulus ( $q$ ) from the Middle Jurassic La Voulte Lagerstätte. Abbreviations: a1, antennula (blue-grey): a2 antenna; mxp3, maxilliped 3; o, eye; P1, first pereiopod (yellow); P2, second pereiopod (green); P3, third pereiopod (blue); P4, fourth pereiopod (magenta); P5, fifth pereiopod (cyan). Scale bar: $5 \mathrm{~mm}$.

Figure 4: Virtual dissection (Manually reconstructed surface models based on XTM in ventral view) of the cephalic region of Voulteryon parvulus ( $($ ) from the Middle Jurassic La Voulte Lagerstätte (A), third maxillipeds removed (B), all maxillipeds removed (C), maxillipeds and maxillae removed $(D)$, isolated antennula $(E)$, isolated antenna $(F)$, mandible with mandibular palp (G), second maxillae and maxillipeds (H). Abbreviations: a1, antennula (blue-grey); a2, antenna (lilac); ba, basis; bp, basal podomeres; ca, carpus; cox, coxa; da, dactylus; fg, flagellum; ip, incisor process; is, ischium; $\mathbf{m d}$, mandible; $\mathbf{m d p}$, mandible incisor process; $\mathbf{m e}$, merus; $\mathbf{m \times 2}$, maxilla 2 ; $\mathbf{m x p} 1$, first maxilliped (dark blue); $\mathbf{m x p 2}$, second maxilliped (blue); mxp3, third maxilliped (red); o, eye (brown); on, optic nerve? ; pro, propodus; rp?, renal process (?); tp, tripartite peduncle. Scale bars: $2 \mathrm{~mm}$.

Figure 5: XTM reconstruction of anatomy of Voulteryon parvulus ( $(+)$ from the Middle Jurassic La Voulte Lagerstätte. A, lateral view, gills omitted; B, dorsal view; C-F, XTM virtual slices through stomach showing pyloric stomach (C), gastric mill (D-E) and cardiac stomach 
(walls in yellow) with undigested fragments (blue) (F). Outline of exoskeleton in grey; outline of the vaulted area of shield in grey dashed-line; position of virtual slices indicated by colored segments in (B) Abbreviations: a1, antennula; a2, antenna; ai, ampulary inferior ossicle; ar, ampulary roof ossicles; ch, cephalic horn of ovary; cs, cardiac stomach; csw, cardiac stomach wall; $\mathbf{d t}$, digestive tract; ep, ocular peduncle; frag, undigested fragments; gc, gill chamber; Itl, gastric mill left lateral tooth; Itr1-2, grastric mill right lateral tooth 1-2; mam1, thick dorsal mandible abductor muscle; $\mathbf{m d}$, mandible; $\mathbf{m d p}$, mandibular palp; $\mathbf{m \times 2}$, maxilla 2; mxp1-3, maxilliped 1-3; o, eye; on, optic nerve?; ov, ovary; ps, pyloric stomach; th, thoracic horn of ovary; uc, urocardiac ossicle; xp?, exopyloric ossicle(?). Scale bars: $5 \mathrm{~mm}$ (AB), $0.5 \mathrm{~mm}$ in C and $1 \mathrm{~mm}$ in D.

Figure 6: Polycheles amemiyai Yokoya, 1933 partially buried in sediment in Okinawa Churaumi Aquarium. (C) Takuo Higashiji, Okinawa Churaumi Aquarium). Scale bar: $5 \mathrm{~cm}$. 


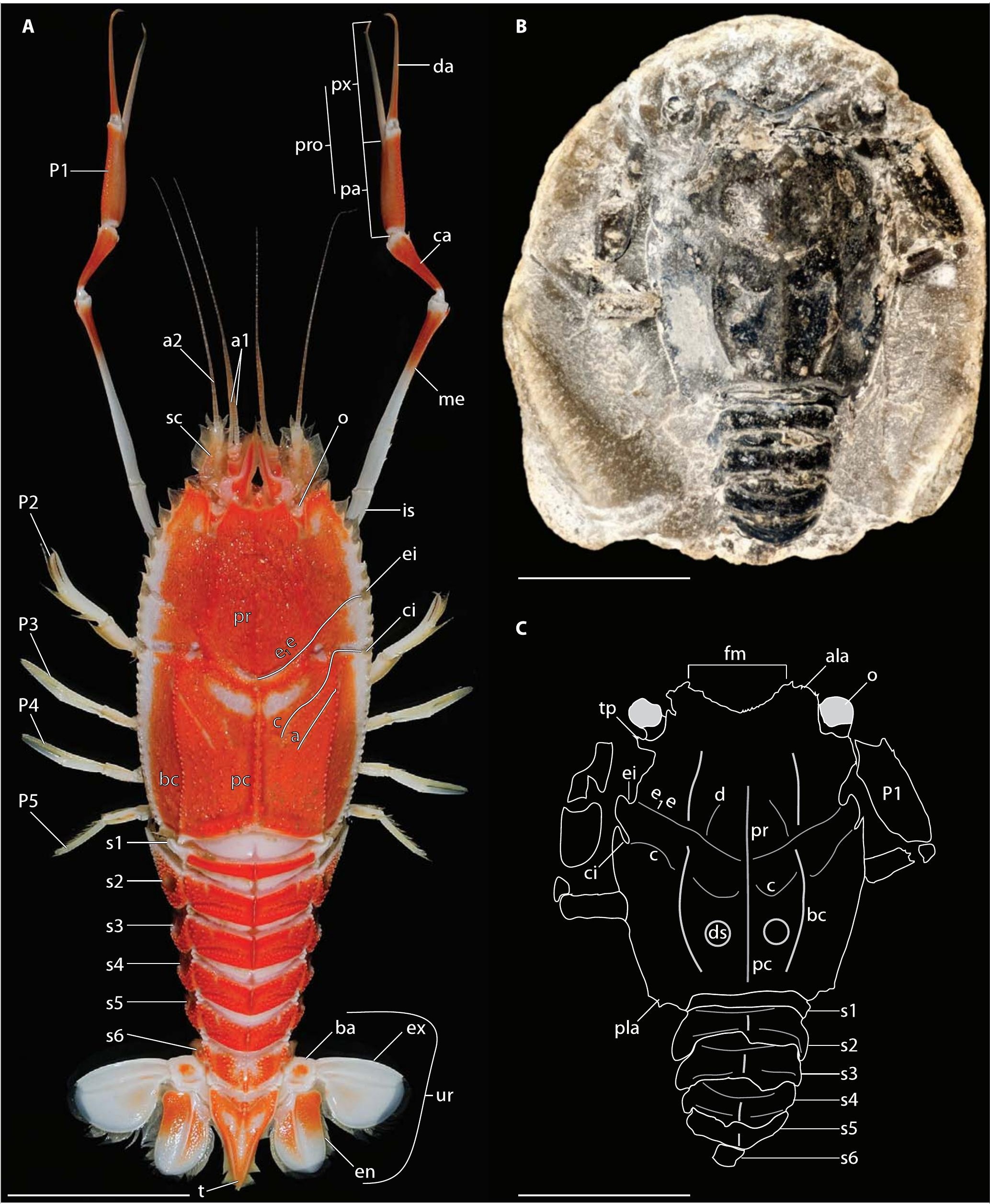



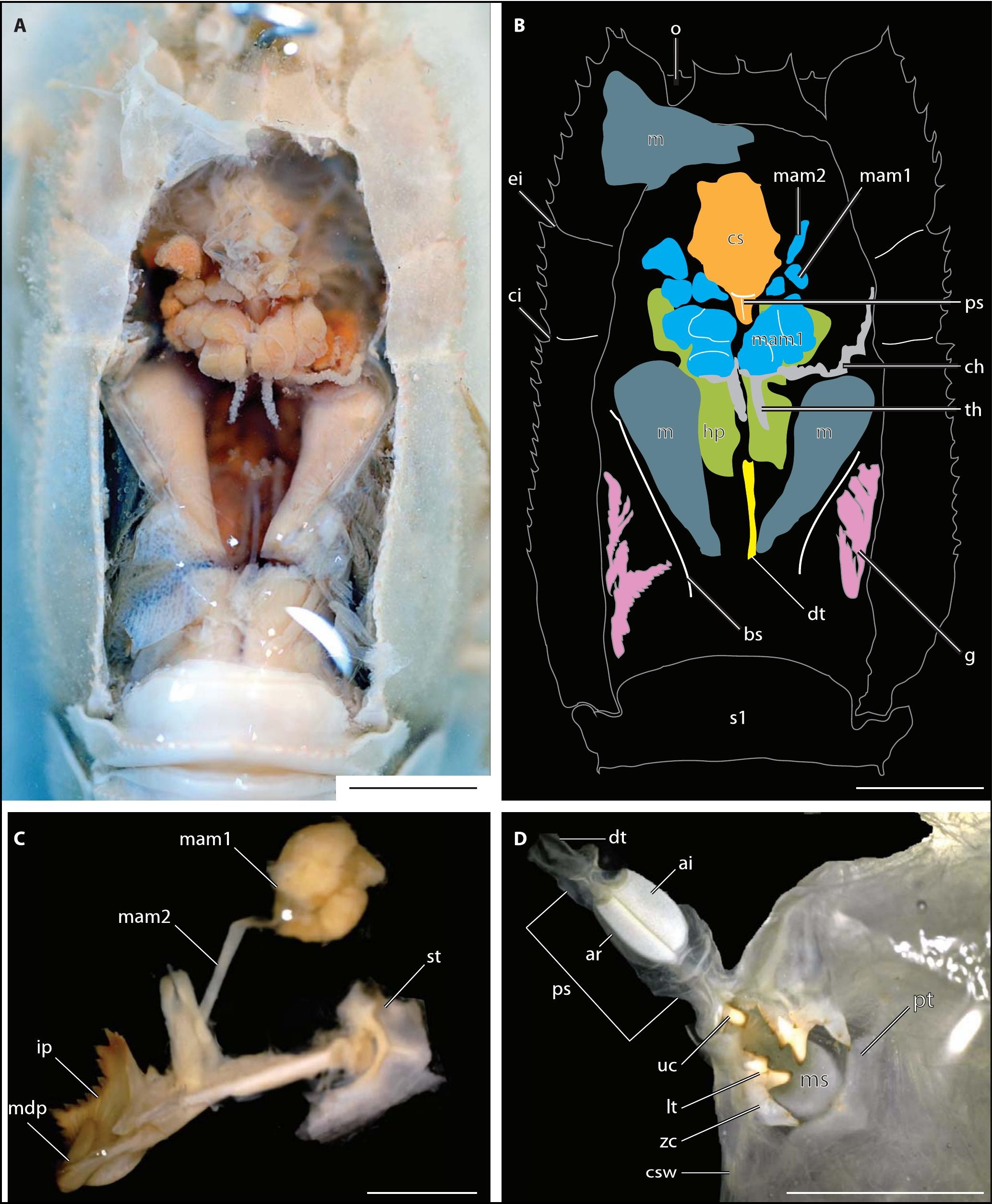


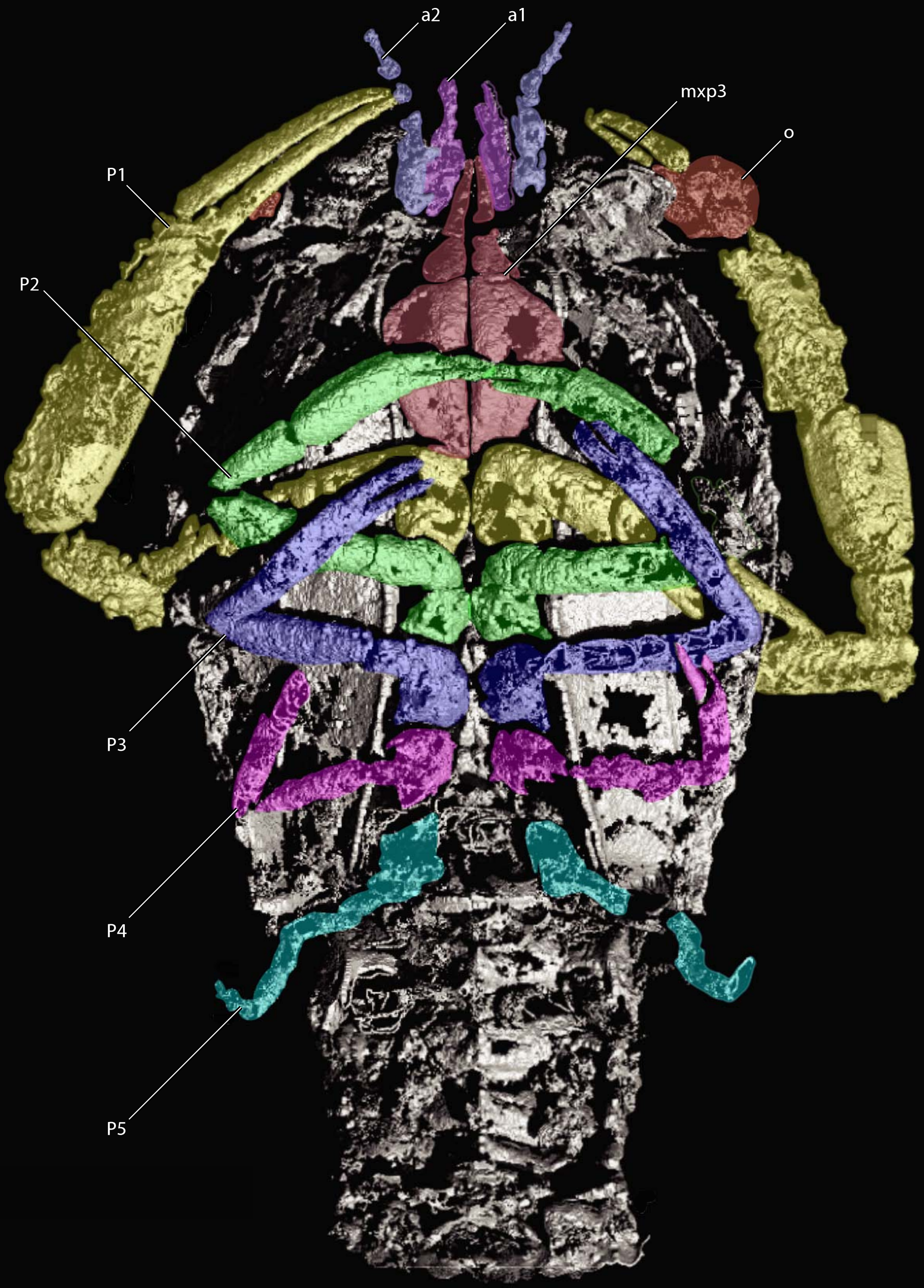


A

OV

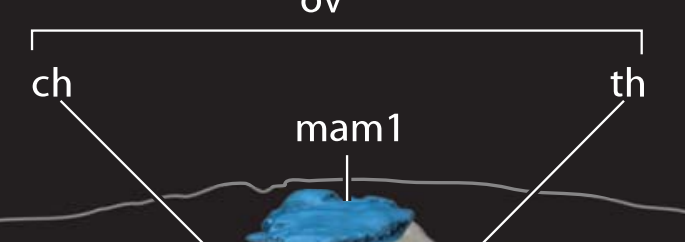

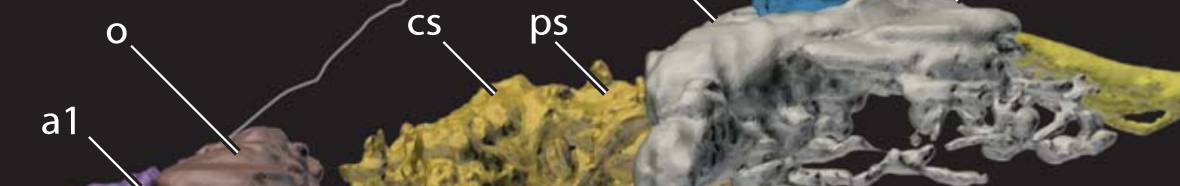

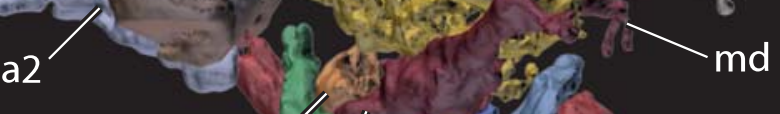

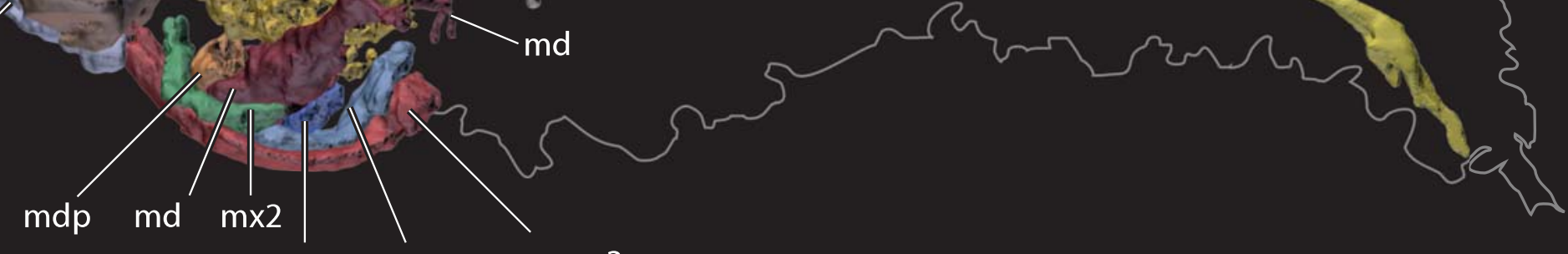

$\operatorname{mxp} 1 \operatorname{mxp} 2 \quad \operatorname{mxp} 3$

B

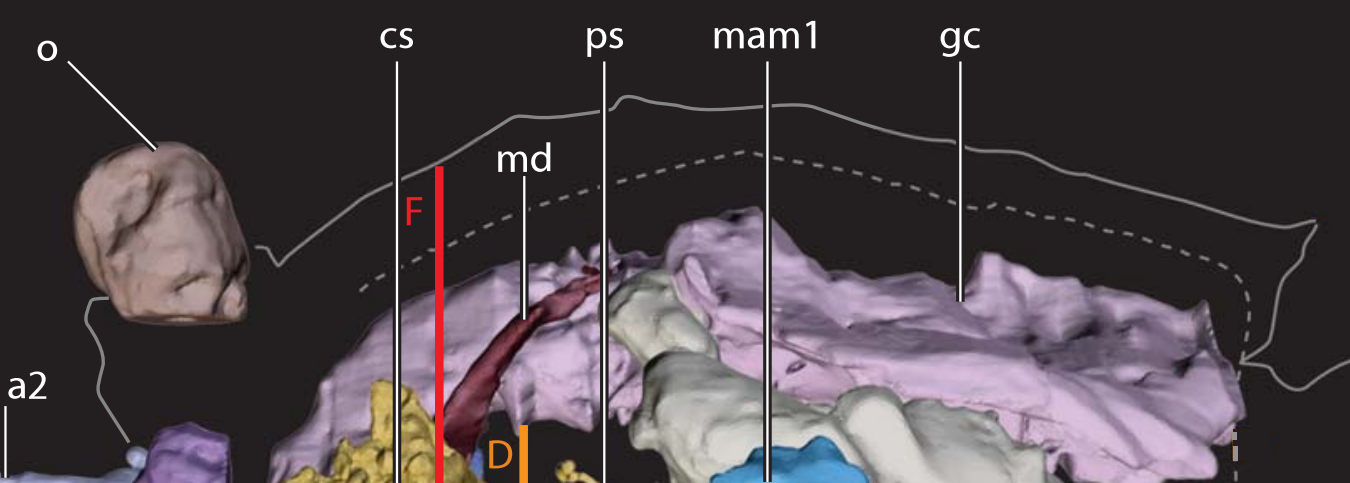

a1
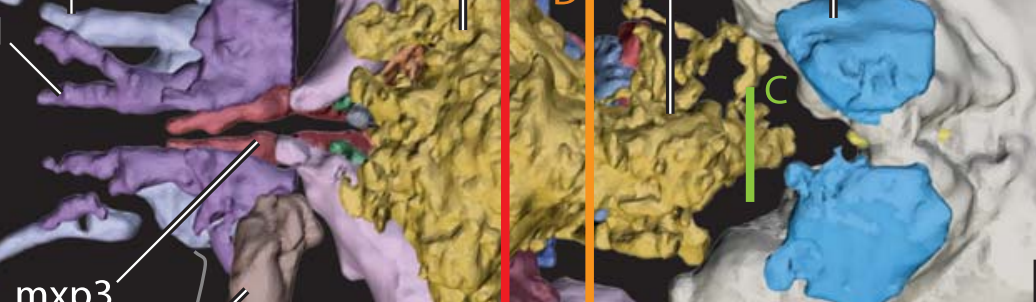

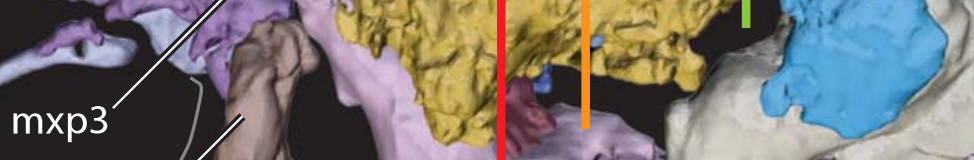
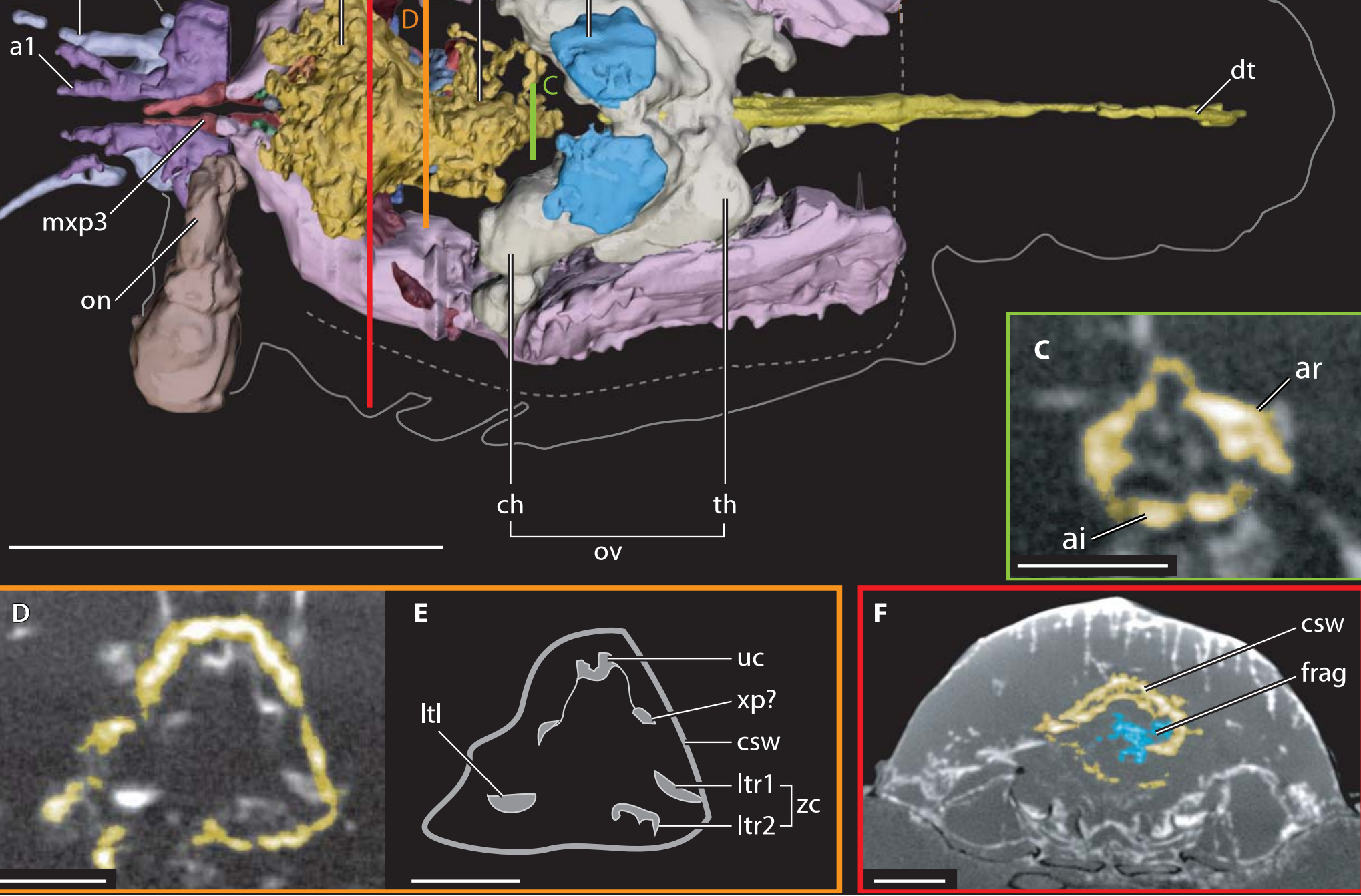


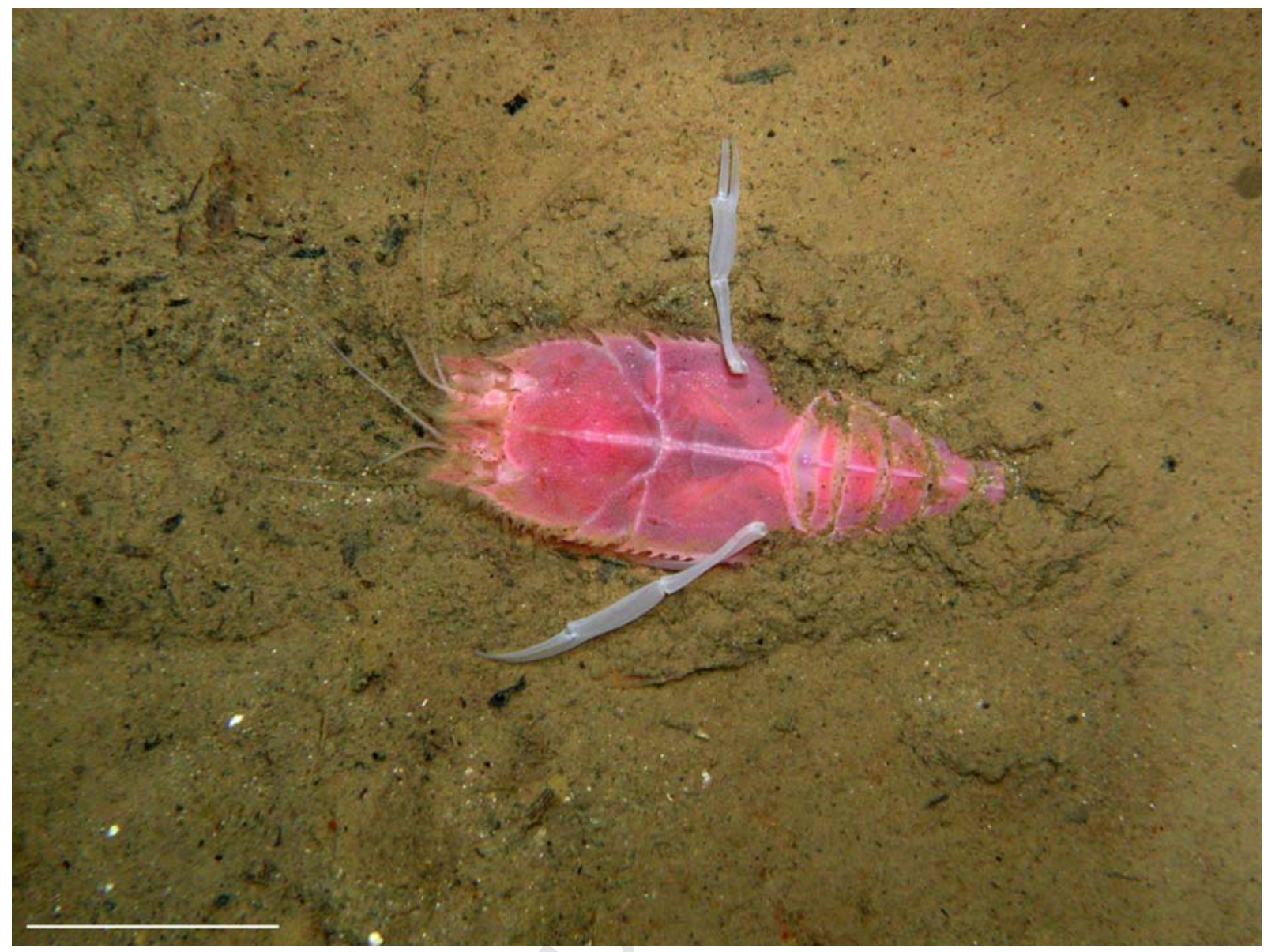




\section{Highlights}

-X-Ray tomography of a crustacean from the La Voulte Lagerstätte $-3 \mathrm{D}$ reconstruction of its morphology (incl. digestive and reproductive systems) -First description of a polychelidan ovigerous female from the Mesozoic -Insights into the possible lifestyles of Mesozoic polychelidan lobsters 